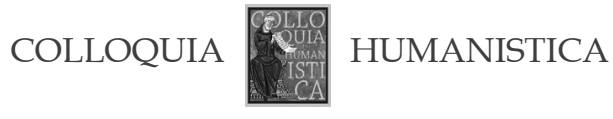

Ewa Łukaszyk

Faculty of "Artes Liberales"

University of Warsaw

\title{
Why Minor, Not Major?
}

Why should we study minor literatures, minor cultures, minor languages? Are not they, by definition, second in order, less essential, less important? Undoubtedly, this point of view predominated for many decades in literary, linguistic and cultural studies in Poland, Eastern Europe and elsewhere, both in the the traditional philological approach, which closely related the study of literatures with research concerning the languages in which they were written, and in literary comparativism, a current that reached the peak of its popularity during the 1980 's. This vogue, anterior to the recent rebirth of the concept of "world literature", had a strong tendency to concentrate on "major" literatures, building a Eurocentric (or Western-Eurocentric) vision that became its main limitation, as resumed by Gayatri Spivak in her book under the suggestive title, Death of a Discipline (2003).

The geography of scholarly interests was reflected in the organization of the faculties. Evidently, when the departments of philology were still under construction, it was logical to do first things first and to invest in the major languages, literatures and cultures before the minor ones. As the years went on, the investment and the academic interests shifted to new fields, progressively making our map of the world more and more complete. Just a few years earlier, the possibility of studying Catalan could be a novelty; now, it has become normal for our students (I refer to my own Faculty of "Artes Liberales" at the University of Warsaw) to be confronted with the option of studying such languages as Nahuatl, and to take it very seriously. Minor literatures offer new fields of research for young scholars, tempting with the possibilities of doing things that have not been done before. 
Emergent literary phenomena give to the scholar a fascinating opportunity of seeing cultural identities in statu nascendi, or accompanying the rebirth of ancient cultures leaving the shadow of the systems that had reduced them for centuries to a subaltern position. Quite often there is also a possibility of participation, assisting and helping peoples in their emancipation and quest for independent expression. These are new tasks that go far beyond the traditional philology and situate the researcher very far from anything that might look like a dusty library.

It was in 1975, nearly forty years ago, that Gilles Deleuze and Félix Guattari published their crucial work on Kafka, changing the dominant perspective concerning minority in literature. Being minor has been considered ever since a key value, opening the perspective of questioning and innovation. It could be said that the condition of being minor became a central issue of contemporary humanities, as a crossing point for approaches starting from opposite ideological premises. Minority became a crucial term for an extensive, interdisciplinary field of subaltern studies, but also for a traditionalist literary critic such as Harold Bloom, who saw the key to the understanding of the literary process in the struggle for originality, led by a minor poet against his or her great predecessors. Nonetheless, newer approaches to the problem of minor cultures and literatures, going in different directions, are worth mentioning too. Over the last quarter of a century, we could observe a massive, global phenomenon of a literary springtime of the peoples. In vast areas of the globe, where the traditional ethnology used to locate so called "oral cultures", defined precisely by the lack of writing systems, even if not a total lack of literature, emergent writing phenomena can be observed, quickly attracting international attention and often acquiring a considerable prominence on the global literary market. Would it be an exaggeration to say that in the world there is more literature now than there used to be ever before? The bulk of this production should be situated in the domain to which the term "minor literatures" is applicable. World literature, a concept that has been, since 2003, successfully reintroduced into the discussion by David Damrosch, is in fact a metasystem in relation to which all local, regional or national literatures are tributary. In a sense, in the globalized reality, all literatures are "minor".

Nonetheless, the emancipation of minor cultures and the flourishing of minor literatures is not always propitious for minor languages. New literatures of minor cultures, in search of the reading public and the organized book markets, often adopt major languages. Putting down his or her own linguistic tools is a legitimate option for the native writer who, as any other writer, may, in the first place, seek a wider readership, 
fame or even profit. Though it should be noted that the interconnections and cause-effect sequences in this domain are far from linear. Be it as it may, we are living in times of doom for minor languages, which are massively losing their speakers in favor of the major tongues. The task of revitalization is urgent and all the attention focused on the minor languages is more than justified. In many cases, the only thing that the researcher can do is to document them before they disappear. Nonetheless, even such documentation is an important task. Even if the probability that some of these languages might one day be reborn from the ashes and reintroduced to everyday communication is very low, we still need to preserve at least some trace of humanity's linguistic diversity. It is a task that concerns all of us, not only the peoples whose direct heritage these languages are. We are still unable to answer many of the fundamental questions in linguistics, concerning such aspects as the origin of human speech and the general traits or structures that underlie all human forms of communication. If languages continue dying at the pace they do, soon we will have no material left to carry on this quest any further.

These questions, central to the humanities today, justify the choice of the topic for this issue of "Colloquia Humanistica". The joint efforts of the authors who contributed to it, evidently cannot cover either the vastness of the problems, or the geographic diversity of the world's minor cultures, literatures and languages. Nonetheless, some examples have been chosen, illustrating the research problems that are currently topical and bringing to the general academic consciousness cultural realities that we are still less familiar with.

The thematic section dedicated to minor languages, minor literatures and minor cultures is divided into three sub-sections presenting different aspects of the minor condition and reflecting different methodological inspirations. The first sub-section, under the title "From the Temptation of Minor Literature to the Rejection of Minor Condition", gathers the contributions on Irish, Scottish, Yiddish and Tunisian cultural contexts, where the "objective" condition of being minor or simply "small" in size becomes a starting point for reflection and literary or ideological elaboration. Paradoxically, being minor may be a coveted position, not just a negative circumstance, as the concept of cultural and literary minority is associated with such values as uniqueness and authenticity. Discussing the post-traumatic dimension of contemporary Irish literature, where the trauma seems to be caused by independence and the necessity of abandoning the status of a "victim-culture", Leszek Drong calls our attention to recent Irish fiction's claim to a minority status. This claim sounds very strange, due to the central position that Irish literature occupied in the context 
of European modernity. Nonetheless, adopting a minor position, Irish authors may enable the mechanisms of "subversive writing" in the process of reinterpretation of national history. Aniela Korzeniowska presents quite an opposite point of view in her essay on Scotland: the denial of minority and the rejection of reductive identity of a "small country". Her exhaustive presentation of the contemporary Scottish literature in its manifold manifestations serves as a proof of a non-minor status. "Yiddishism", a kind of ideological development issuing from a mere linguistic fact (the existence of Yiddish as a tongue) is presented by Aleksandra Geller. Finally, my own essay on Tunisian literature gives a glimpse of this little known cultural reality, divided between the temptations of two literary languages: Arabic and French.

The following sub-section, "Identity as Construct and Choice: Historical, Linguistic and Ethnolinguistic Perspectives" offers to the reader an insight into Albanian, Balkan and Eastern-European cultural and linguistic realities. The article by Irena Sawicka shows the Albanian culture (and the language) as a result of crisscrossing influences superimposing throughout its history to form a unique, essentially multicultural reality. The Aromanian Farsheroti dialect, presented by Marjan Markovik' is another example of such complex reality reflected in a unique linguistic phenomenon. Finally, Izabela Olszewska and Ines Ackermann take us back to the margins of the Polish linguistic zone, showing the difficult contexts of choice and selfdetermination in the domain of language and identity: those of the Free City of Danzig and of the post-Soviet space.

Finally, the third sub-section, "From Tormented History to Projects of Revitalization for the Future", evokes Latin American reality in the articles by Justyna Olko and John Sullivan on Nahuatl and by Aleksandra Bergier on Guaraní, as well as Brittany in the essay by Nicole Dołowy-Rybińska. Another type of problem, related to the preservation of endangered cultural diversity and revitalization of minor cultures is introduced. It requires a different methodological approach, that of field-work, implying the direct participation of the researcher. No wonder that the articles introduce, as a background for the analysis, some accounts of personal encounters with the minor culture which has been studied. This involvement of the academia into living cultures in their becoming and emancipation opens the perspective of preservation of cultural diversity as the common heritage of humanity, showing that diverse minor conditions in the world are not just local realities, often reduced in our consciousness to a mere folkloric status, but a matter that requires an international solidarity. Thus, this closing section fully reflects the mission inscribed in the title of "Colloquia Humanistica". 